\title{
Variation of beneficial effects of Trichoderma harzianum by the maize variety under water stress
}

\author{
J. Chepsergon, L. A. Mwamburi and K. E. Kiprop
}

Department of Biological Sciences. University of Eldoret. Kenya.

\begin{abstract}
The aim of the study was to out whether the beneficial effect of T. harzianum in enhancing maize seed germination and seedling growth under water stress is dependent on the maize variety soil samples were collected from Marigat Rangeland, Kenya. Trichoderma harzianum was isolated using macro and micro-morphological characteristics. The present study employed a three-factor factorial ( $3 \times 2 \times 2)$ design, arranged in a completely randomized design (CRD) with three replications. There was no significant $(p>0.05)$ difference in percentage germination, seedling length, fresh weight, shoot-root dry weight, superoxide dismutase and catalase activities among the three varieties of maize. In addition, significant differences in seed germinations, seedling growth parameters and antioxidant enzyme enzymes were recorded between treated and control plants among the three varieties of maize. Maize variety had no significant influence on the beneficial activity of T. harzianum.
\end{abstract}

Keywords: Maize varieties; Water stress; T. harzianum.
Received

July 21, 2018

Accepted

August 26, 2018

Released

August 31, 2018

Full Text Article

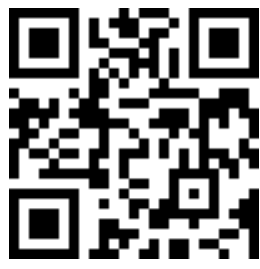

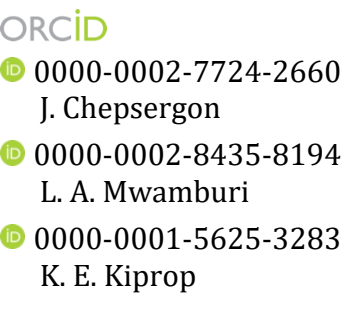

\section{Introduction}

Water stress or drought stress is an inevitable and recurring feature of global agriculture. It is one of the most devastating environmental stresses. Water stress limits growth and productivity of main crop species, reducing yields to less than half (Bayoumi et al., 2008). Also it has been reported that, about one-third of the world's potentially arable land suffers from water shortage (Kramer, 1980). Trichoderma spp. are the most common research tools as microbial inoculants which have been mostly used as biocontrol agents. However, in the recent years, they have become popular as plant growth promoters (Hermosa et al., 2012). For Trichoderma to effectively augment plant development, it must be able to establish in the spermosphere of germinating seeds, distribute on the emerging radicle and colonize the developing root (Orr and Knudsen, 2004).

There is no doubt that in both academic research and commercial 
practice, $T$. harzianum has been revealed to increase seedling emergence and growth in maize and numerous other plants. The effect of the fungus has been reported to last for the entire life of most annual plants. However, Harman et al. (2004) found out that, there was a strong genetic component to the yield and plant-growth enhancement that is drawn out by $T$. harzianum strain $\mathrm{T}-22$. The study using maize plant further revealed that inbred line Mo17 responded to T-22 most, other lines responded only weakly, while a few in fact showed a reduction in growth and yield. This difference in response is owed to variation in the transcriptome or proteome level. Tucci et al. (2011) through an experiment on tomato seedlings revealed that the level of seed germination and seedling growth stimulation was mostly dependent on the tomato genotype, signifying that the response to Trichoderma spp. was genetically controlled. In the same study most lines responded to T. harzianum. Genetic analysis has demonstrated that the maize response is largely conditioned by dominant genes (Harman, 2006). Moreover, Liu et al. (1995), further revealed that genetic background affected the response of different cucumber varieties to PGPR species which really are considered to share with Trichoderma spp. similar mechanisms of (ITR) (Harman et al., 2004).

Therefore, the present study sought to find out whether the beneficial effect of $T$. harzianum in enhancing maize seed germination and seedling growth under water stress is dependent on the maize variety.

\section{Materials and methods}

\section{Sample collection and isolation of T. harzianum}

About $60 \mathrm{~g}$ of soil sample was randomly obtained from bare soil in 10 $\mathrm{cm}$ depth under at Marigat Rangeland, Kenya, using a sterile soil auger, transferred into sterile polyethylene bags and transported to the Laboratory of
Microbiology, University of Eldoret, within $24 \mathrm{~h}$ of collection.

Isolation Trichoderma harzianum from soil was done by using a modified method of Papavizas and Lumsden (1982). $10 \mathrm{~g}$ of the soil samples were thoroughly mixed together to make a composite and thereafter made up to $1,000 \mathrm{~mL}$ using sterile distilled water in a sterile conical flask. The soil suspension was left for $1 \mathrm{~h}$ at room temperature to release conidia and hyphae adhering to soil particles. Serial dilutions up to $10^{-3}$ were prepared. $1 \mathrm{~mL}$ aliquots were spread-plated onto Potato Dextrose Agar (PDA) medium supplemented with $50 \mathrm{mg} / \mathrm{L}$ of streptomycin antibiotic to inhibit bacterial growth. The plates were then incubated at $28^{\circ} \mathrm{C}$ and $35^{\circ} \mathrm{C}$ for 7 days. The Hassan et al. (2014) procedure was adopted for production of T. harzianum inoculum. However, slight modification was made to suit the present study.

\section{Maize seed selection and treatment}

Maize seeds with no cracks or any visible deformations were obtained from Kenya Seed Company Kitale. It is the leading seed company in Kenya and a good number of farmers acquire their seeds from here. Maize varieties (H614, H629 and H6210) were used in the study because they have been reported to be highly susceptible to drought stress. More so, these varieties are being planted by most farmers within Uasin Gishu and Trans Nzoia Counties which are the main maize producing counties in Kenya. Surface sterilization was done for 5 min with $1 \%$ sodium hypochlorite solution, followed by rinsing with distilled water three times and finally air dried. Wet seed treatment method was adopted, where seed coating was done by applying $2 \%$ of starch (adhesive) on the maize seeds. Subsequently, maize seeds were dipped in seed coating suspension of $1 \times 10^{7} \quad$ spores $/ \mathrm{mL}$ T. harzianum for $2 \mathrm{~min}$. Control seeds 
were treated with autoclaved cells of T. harzianum.

\section{Determination of seedling emergence}

The present study employed a three-factor factorial $(3 \times 2 \times 2)$ design, arranged in a completely randomized design (CRD) with three replications each. The first factor was the maize seed varieties (H614, H629 and H6210), second factor was the treatment of Trichoderma harzianum (0 and $1 \times 10^{7}$ spores $/ \mathrm{mL}$ ) and the third one was the osmotic potential levels ( 0 and $-0.9 \mathrm{MPa}$ ). Seedling emergence assays was performed based on Achakzai (2009). Sterilized maize seeds were treated with Trichoderma harzianum at $\left(0\right.$ and $1 \times 10^{7}$ spores $/ \mathrm{mL}$ ). Ten seeds were evenly distributed in each sterile Petri dish lined with two layers of Whatmann filter paper saturated with $8 \mathrm{~mL}$ of polyethylene glycol (PEG) solution to mimic drought stress. The plates were then incubated at $25^{\circ} \mathrm{C}$. Observations regarding germination were made after every $24 \mathrm{~h}$, and continued till the completion of germination. The emergence of radical and plumule was taken as an indicator or measure of germination. After 7 days the $\%$ germination was determined using the formula by Achakzai (2009).

\section{growth}

Determination of seedling

After 10 days of germination, three seedlings from each Petri dish were taken out randomly. Washing was done gently to avoid losing some parts of the seedling and growth measurements were taken (Seedling Length, Seedling Fresh Weight - SFW, Root Dry Weight RDW and Shoot Dry Weight - SDW).

\section{Assay of Superoxide Dismutase (SOD) and Catalase (CAT) activity \\ Extraction of (SOD and CAT) enzymes from plant samples was done according to Higuchi et al. (2008). Both}

water stressed and control maize seedlings were evaluated for antioxidative enzymes' activity after 10 days of germination. Fresh weight of $0.5 \mathrm{~g}$ leaf sample was taken and then placed in a freezer at $-10{ }^{\circ} \mathrm{C}$ for $24 \mathrm{~h}$. The frozen leaf sample was then finely ground by pestle in a frozen motor to prevent the loss of enzymes' activities. The frozen powder was added to $10 \mathrm{~mL}$ of phosphate buffer $(\mathrm{pH}$ 7.5). The homogenate was centrifuged at $15,000 \times \mathrm{g}$ for $10 \mathrm{~min}$ at $25^{\circ} \mathrm{C}$ and supernatant was used as enzyme source for catalase (CAT) and superoxide dismutase (SOD) (Higuchi et al., 2008). Determination of CAT and SOD activities were done according to Lum et al. (2014).

\section{Statistical analysis}

The mean values of seedling parameters, SOD and CAT enzymes activity were taken from measurements of the three replicates and standard error (SE) of the means was calculated. The mean values were then analyzed by three- way analysis of variance (ANOVA) using statgraphics programme. Means were separated using Tukey's test at 5\% significance level.

\section{Results and discussion}

There was no significant $(p>0.05)$ difference in percentage germination among the three varieties of maize at the same osmotic potential with the same spore concentration of T. harzianum.

At $0 \mathrm{MPa}$, optimum percentage germination $(95 \%)$ was recorded in both T. harzianum treated and untreated maize seeds but it decreased as the moisture stress increased in all the three varieties of maize. Minimum percentage germination $(13 \%)$ was recorded in untreated maize seeds at $-0.9 \mathrm{MPa}$, while treated maize seeds showed significant higher $(54 \%)$ percentage germination than untreated seeds (Figure 1). 


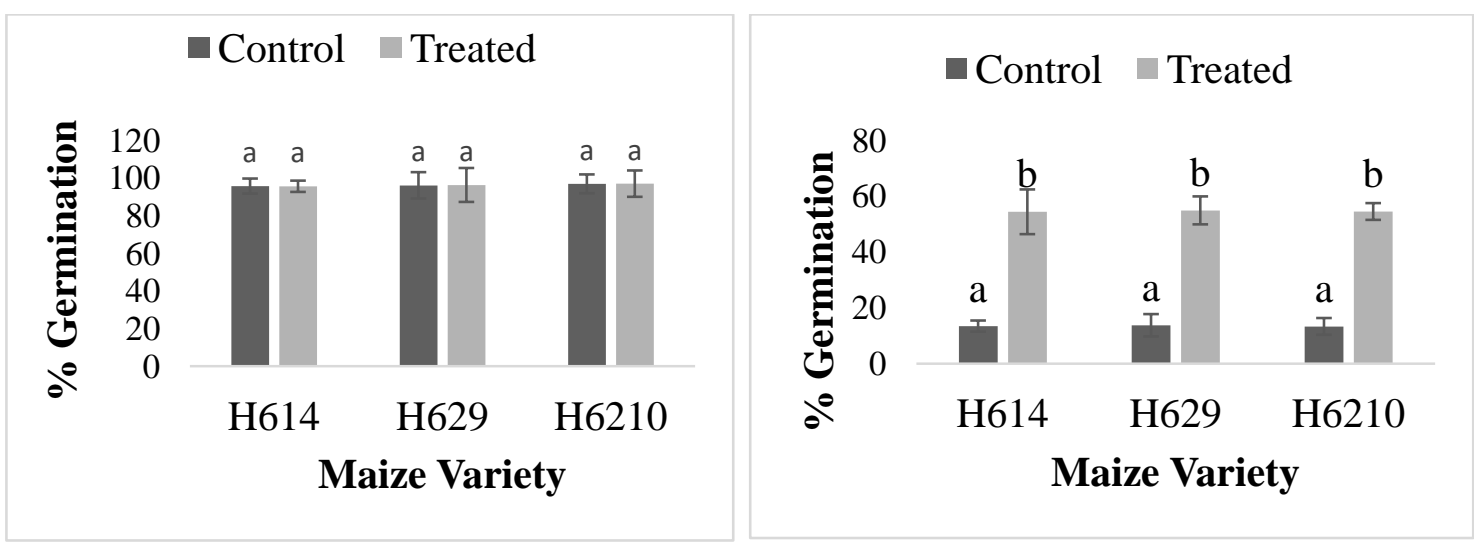

Figure 1. Effect T. harzianum on percentage germination of three maize varieties at $0 \mathrm{MPa}(\mathrm{a})$ and $-0.9 \mathrm{MPa}(\mathrm{b})$ conditions.

There were no significant $(p>0.05)$ differences in seedling length and fresh seedling weight among the three varieties of maize at the same osmotic potential. At $-0.9 \mathrm{MPa}$, seedling length increased significantly $(\mathrm{p}<0.05)$ from $1.6 \mathrm{~cm}$ in control to $5.7 \mathrm{~cm}$ in seedlings treated with $10^{7}$ spores' $/ \mathrm{mL}$ of T. harzianum.
At $-0.9 \mathrm{MPa}$, reduced SFW was recorded in both treated and untreated seedlings across the three maize varieties (Table 2). However, SFW increased significantly $(\mathrm{p}<0.05)$ from $0.5 \mathrm{mg} /$ seedling in control to 01.3-1.4 $\mathrm{mg} /$ seedling in seedlings treated with $10^{7}$ spores/mL of $T$. harzianum.

Table 1: Effect T. harzianum on maize seedling length and fresh seedling weigh of three maize varieties at $0 \mathrm{MPa}$ and $-0.9 \mathrm{MPa}$.

\begin{tabular}{|c|c|c|c|c|c|}
\hline \multirow{2}{*}{\multicolumn{2}{|c|}{$\begin{array}{c}\text { Water } \\
\text { potential }\end{array}$}} & \multicolumn{2}{|c|}{ Seedling length $(\mathrm{cm})$} & \multicolumn{2}{|c|}{ Fresh seedling weight (mg/seedling) } \\
\hline & & Control & Treated & Control & Treated \\
\hline \multirow[t]{2}{*}{ H614 } & 0 & $12.72 \pm 0.03 b$ & $14.567 \pm 0.04 \mathrm{~b}$ & $2.48 \pm 0.001 b$ & $3.57 \pm 0.001 b$ \\
\hline & -0.9 & $1.63 \pm 0.01 \mathrm{a}$ & $5.644 \pm 0.01 \mathrm{a}$ & $0.50 \pm 0.001 \mathrm{a}$ & $1.31 \pm 0.001 \mathrm{a}$ \\
\hline \multirow[t]{2}{*}{ H629 } & 0 & $12.72 \pm 0.02 b$ & $14.582 \pm 0.03 b$ & $2.51 \pm 0.004 \mathrm{~b}$ & $3.61 \pm 0.004 b$ \\
\hline & -0.9 & $1.618 \pm 0.04 \mathrm{a}$ & $5.621 \pm 0.04 \mathrm{a}$ & $0.53 \pm 0.003 a$ & $1.39 \pm 0.003 a$ \\
\hline \multirow[t]{2}{*}{ H6210 } & 0 & $12.77 \pm 0.04 \mathrm{~b}$ & $14.5970 \pm 0.01 b$ & $2.57 \pm 0.001 b$ & $3.67 \pm 0.001 b$ \\
\hline & -0.9 & $1.67 \pm 0.04 \mathrm{a}$ & $5.667 \pm 0.02 \mathrm{a}$ & $0.51 \pm 0.003 \mathrm{a}$ & $1.42 \pm 0.001 \mathrm{a}$ \\
\hline
\end{tabular}

The results of the study further showed that maize varieties did not differ significantly in shoot dry weight (SDW) and root dry weight (RDW) at the same osmotic potentials within the same spore concentration of T. harzianum.

At $-0.9 \mathrm{MPa}$, SDW increased significantly $(\mathrm{p}<0.05)$ from $0.05-0.06$ $\mathrm{mg} /$ seedling in control to $0.17-0.19$ $\mathrm{mg} /$ seedling in seedlings treated with
$10^{7}$ spores/mL of T. harzianum. Likewise, RDW was significantly reduced at $-0.9 \mathrm{MPa}$ in both treated and untreated seedlings in all the three varieties of maize (Table 2). Nevertheless, RDW increased significantly $(\mathrm{p}<0.05)$ from $0.05-0.06 \mathrm{mg} /$ seedling in control to 0.39 $0.42 \mathrm{mg} / \mathrm{seedling}$ in seedlings treated with $10^{7}$ spores/ml of T. harzianum as shown in Table 2. 
Table 2. Effect T. harzianum on maize shoot and root dry weight of three maize varieties at $0 \mathrm{MPa}$ and $-0.9 \mathrm{MPa}$.

\begin{tabular}{lccccc}
\hline \multirow{2}{*}{$\begin{array}{c}\text { Maize } \\
\text { Variety }\end{array}$} & Water & \multicolumn{2}{c}{ Shoot dry weight (mg/seedling) } & \multicolumn{2}{c}{ Root dry weight (mg/seedling) } \\
\cline { 2 - 5 } & & Control & Treated & Control & Treated \\
\hline H614 & 0 & $0.34 \pm 0.002 \mathrm{~b}$ & $0.42 \pm 0.003 \mathrm{~b}$ & $0.41 \pm 0.017 \mathrm{~b}$ & $0.69 \pm 0.005 \mathrm{~b}$ \\
& -0.9 & $0.05 \pm 0.004 \mathrm{a}$ & $0.17 \pm 0.004 \mathrm{a}$ & $0.06 \pm 0.016 \mathrm{a}$ & $0.40 \pm 0.007 \mathrm{a}$ \\
$\mathrm{H} 629$ & 0 & $0.31 \pm 0.001 \mathrm{~b}$ & $0.41 \pm 0.003 \mathrm{~b}$ & $0.40 \pm 0.015 \mathrm{~b}$ & $0.65 \pm 0.017 \mathrm{~b}$ \\
& -0.9 & $0.05 \pm 0.001 \mathrm{a}$ & $0.18 \pm 0.001 \mathrm{a}$ & $0.05 \pm 0.009 \mathrm{a}$ & $0.42 \pm 0.015 \mathrm{a}$ \\
$\mathrm{H} 6210$ & 0 & $0.33 \pm 0.003 \mathrm{~b}$ & $0.43 \pm 0.003 \mathrm{~b}$ & $0.42 \pm 0.021 \mathrm{~b}$ & $0.61 \pm 0.004 \mathrm{~b}$ \\
& -0.9 & $0.06 \pm 0.001 \mathrm{a}$ & $0.19 \pm 0.005 \mathrm{a}$ & $0.05 \pm 0.020 \mathrm{a}$ & $0.39 \pm 0.017 \mathrm{a}$ \\
\hline
\end{tabular}

At $0 \mathrm{MPa}$, SOD activity increased significantly $(\mathrm{p}<0.05)$ from $15.0 \mathrm{U} \mathrm{g}^{-1}$ protein in control to $15.2 \mathrm{U} \mathrm{g}^{-1}$ protein in seedlings treated with $10^{5}$ spores/mL of T. harzianum. Further increase $(15.5 \mathrm{U}$ $\mathrm{g}^{-1}$ protein) in SOD activity was recorded in seedlings treated with $10^{7}$ spores $/ \mathrm{mL}$ of $T$. harzianum. At $-0.9 \mathrm{MPa}$, SOD activity increased significantly $(\mathrm{p}<0.05)$ from $194 \mathrm{U} \mathrm{g}^{-1}$ protein in control to $337 \mathrm{U} \mathrm{g}^{-1}$ protein in seedlings treated with $10^{5}$ spores/mL of $T$. harzianum. Maximum SOD activity (893 $\mathrm{U} \mathrm{g}^{-1}$ protein) was recorded in seedlings treated with $10^{7}$ spores/mL of $T$. harzianum as indicated in Table 3.

Table 3. Effect T. harzianum on maize shoot and root dry weight of three maize varieties at $0 \mathrm{MPa}$ and $-0.9 \mathrm{MPa}$.

\begin{tabular}{|c|c|c|c|c|c|}
\hline \multirow{2}{*}{$\begin{array}{l}\text { Maize } \\
\text { Variety }\end{array}$} & \multirow{2}{*}{ Water } & \multicolumn{2}{|c|}{ SOD activity ( $\mathrm{U} \mathrm{g}^{-1}$ protein) } & \multicolumn{2}{|c|}{$\begin{array}{c}\text { CAT activity }\left(\mu \mathrm{mol} \mathrm{H}_{2} \mathrm{O}_{2} \min ^{-1} \mathrm{~g}^{-1}\right. \\
\text { protein) }\end{array}$} \\
\hline & & Control & Treated & Control & Treated \\
\hline \multirow[t]{2}{*}{ H614 } & 0 & $15.054 \pm 0.06 \mathrm{a}$ & $15.560 \pm 0.07 a$ & $0.016 \pm 0.009 \mathrm{a}$ & $0.097 \pm 0.012 \mathrm{a}$ \\
\hline & -0.9 & $194.379 \pm 0.06 b$ & $893.564 \pm 0.06 b$ & $1.071 \pm 0.008 \mathrm{~b}$ & $4.083 \pm 0.009 \mathrm{~b}$ \\
\hline \multirow[t]{2}{*}{ H629 } & 0 & $15.079 \pm 0.08 \mathrm{a}$ & $15.572 \pm 0.06 \mathrm{a}$ & $0.015 \pm 0.011 \mathrm{a}$ & $0.095 \pm 0.009 \mathrm{a}$ \\
\hline & -0.9 & $194.378 \pm 0.04 b$ & $893.570 \pm 0.1 \mathrm{~b}$ & $1.070 \pm 0.009 b$ & $4.079 \pm 0.007 \mathrm{~b}$ \\
\hline \multirow[t]{2}{*}{ H6210 } & 0 & $15.023 \pm 0.08 \mathrm{a}$ & $15.557 \pm 0.10 \mathrm{a}$ & $0.017 \pm 0.007 \mathrm{a}$ & $0.097 \pm 0.008 \mathrm{a}$ \\
\hline & -0.9 & $194.311 \pm 0.04 b$ & $893.555 \pm 0.07 b$ & $1.075 \pm 0.014 \mathrm{~b}$ & $4.085 \pm 0.011 b$ \\
\hline
\end{tabular}

Similarly, CAT activity increased significantly $(\mathrm{p}<0.05)$ with decrease in osmotic potential in both treated and untreated maize seedling across the three varieties of maize (Table 3). At $0.9 \mathrm{MPa}, \quad \mathrm{CAT}$ activity increased significantly $(\mathrm{p}<0.05)$ from $1.0 \mu \mathrm{mol}$ $\mathrm{H}_{2} \mathrm{O}_{2}$ min-1 $^{-1} \mathrm{~g}^{-1}$ protein in control to 1.3 $\mu$ mol $\mathrm{H}_{2} \mathrm{O}_{2}$ min- $^{-1} \mathrm{~g}^{-1}$ protein in seedlings treated with $10^{5}$ spores $/ \mathrm{mL}$ of T. harzianum. Maximum CAT activity
(4.0 $\mu$ mol $\mathrm{H}_{2} \mathrm{O}_{2}$ min-1 $^{-1} \mathrm{~g}^{-1}$ protein) was recorded in seedlings treated with $10^{7}$ spores/mL of T. harzianum.

\section{Discussion}

Seed germination and seedling growth parameters that were evaluated in this study showed that, maize variety by T. harzianum-concentration interaction was not significant. Also, 
maize variety by T.harzianum concentration by osmotic potential interaction was shown to be insignificant. Therefore, our findings demonstrated that the extent of maize seed germination and early seedling growth stimulation is not largely dependent on the maize variety, suggesting that the response to Trichoderma spp. is not under genetic control. However, from the few studies that have been carried out, plant genotype affects the activity of most plant growth promoting fungi. For example, Harman et al. (2004) clearly showed the importance of the plant genetic background for the interaction between maize and T. harzianum (T22). The authors showed that, commercial trials on several T22-treated hybrids and inbred lines revealed that the expected yield increases in most genotypes, with a few actually showing a yield reduction. Furthermore, genetic analysis has demonstrated that maize response is largely conditioned by dominant genes (Harman, 2000).

Another study by Tucci et al. (2011) clearly showed the importance of plant variety. Using tomato plant, they assessed the beneficial plantTrichoderma interaction for root growth promotion. They reported a significant increase in root dry weight obtained by treating tomato seedlings with Trichoderma spp. However, plant growth promotion differed significantly from different varieties of tomato plant. Results obtained from the present study could be attributed to the fact that, the three varieties that were used in the study belong to a common series (6 series) and therefore, the degree of variation is minimal. Also, the difference could be due to the fact that present study was carried out under water stress conditions while the existing related researches were carried out under water stress- free conditions.

\section{Conclusion}

Maize variety had no significant influence on the beneficial activity of $T$. harzianum. Significant $(\mathrm{p}<0.05)$ seed germination, seedling growth and antioxidant enzymes activity were shown in all the three varieties of maize between treated and untreated seeds.

\section{Acknowledgement}

The financial support by National Council of Science Technology and Innovation (NACOSTI) of Kenya to the project is hereby acknowledged

\section{Conflict of Interest}

The authors declare no conflict of interest.

\section{References}

Achakzai, A. K. K. Effect of water stress on imbibition, germination and seedling growth of maize cultivars. Sarhad J. Agric., v. 25, no. 2, p. 165-172, 2009.

Bayoumi, T. Y.; Eid, M. H.; Metwali, E. M. Application of physiological and biochemical indices as a screening technique for drought tolerance in wheat genotypes. African Journal of Biotechnology, v. 7, no. 14, p. 2341-2352, 2008.

Harman, G. E. Myths and dogmas of biocontrol changes in perceptions derived from research on Trichoderma harzinum T-22. Plant Disease, v. 84, no. 4, p. 377-393, 2000.

Harman, G. E.; Howell, C. R.; Viterbo, A.; Chet, I.; Lorito, M. Trichoderma species opportunistic, avirulent plant symbionts. Nature Reviews Microbiology, v. 2, no. 1, p. 43-56, 2004.

Hassan, M. M.; Daffalla, H. M.; Modwi, H. I.; Osman, M. G.; Ahmed, I. I.; Gani, M. E. A.; Abdel El Gabar, E. B. Effects of fungal strains on seeds germination of millet and Striga hermonthica. Universal Journal of Agricultural Research, v. 2, no. 2, p. 83-88, 2014. 
Hermosa, R.; Viterbo, A.; Chet, I.; Monte, E. Plant-beneficial effects of Trichoderma and of its genes. Microbiology, v. 158, no. 1, p. 17-25, 2012.

Higuchi, T.; Fujimura, H.; Arakaki, T.; Oomori, T. Activities of antioxidant enzymes (SOD and CAT) in the coral Galaxea fascicularis against increased hydrogen peroxide concentrations in seawater. Proceeding of the 11th International Coral Reef Symposium, 2008.

Kramer, P. J. Drought, stress, and the origin of adaptations. In: Turner, N. C.; Kramer, P. J. Adaptation of plants to water and high temperature stress. New York: John Wiley \& Sons, 1980. p. 7-20.

Liu, L.; Kloepper, J. W.; Tuzun, S. Induction of systemic resistance in cucumber against bacterial angular leaf spot by plant growth- promoting rhizobacteria. Phytopathology, v. 85, no. 8, p. 843-847, 1995.

Orr, K. A.; Knudsen, G. R. Use of green fluorescent protein and image analysis to quantify proliferation of Trichoderma harzianum in nonsterile soil. Phytopathology, v. 94, no. 12, p. 1383-1389, 2004.

Papavizas, G. C.; Lumsden, R. D. Improved medium for isolation of Trichoderma spp. from soil. Plant Diseases, v. 66, p. 10191020, 1982. https://doi.org/10.1094/PD-661019

Tucci, M.; Ruocco, M.; De Masi, L.; De Palma, M.; Lorito, M. The beneficial effect of Trichoderma spp. on tomato is modulated by the plant genotype. Molecular Plant Pathology, v. 12, no. 4, p. 341-354, 2011. 